\title{
Chemistry, information and Frank: a tribute to Frank Brown
}

\author{
Dimitris K. Agrafiotis ${ }^{1}$ - M. Katharine Holloway ${ }^{2} \cdot$ Scott Arne Johnson ${ }^{3}$. Charles H. Reynolds ${ }^{2}$. Terry Richard Stouch ${ }^{4}$. \\ Alexander Tropsha ${ }^{5} \cdot$ Chris L. Waller ${ }^{6}$
}

Received: 14 July 2018 / Accepted: 19 July 2018 / Published online: 23 July 2018

C) Springer Nature Switzerland AG 2018

\section{Missing a visionary}

\section{Terry Stouch, Editor}

Sadly this is the 3rd tribute that we have published for founders of computational chemistry within the last year; the other two being Toshio Fujita and David Weininger. We lost Frank Brown when he died suddenly last year. He was a visionary. He was straightforward, open, often blunt, helpful, and carried a good sense of humor. He contributed substantially to our field. He made a difference.

Frank Brown was an early founder of chemoinformatics, as he branded it, now known as cheminformatics. He headed the first dedicated cheminformatics group and published the first paper in the field. He made an impact on most likely everyone he met and then some.

Also, he was my friend. We knew each other since we were both postdocs. We emailed some jokes just days before his demise and not long before that we discussed working together as consultants. He and I saw eye-to-eye on the integration of computational chemistry and cheminformatics into pharmaceutical research. However, I'll keep my comments brief since the other six contributors to this piece knew him even better than I and all paint a vivid picture his scientific impact, his impact on the many people he knew, our friendships, and beyond all his loving family who placed a continual smile on his face.

\footnotetext{
Terry Richard Stouch

TStouch@gmail.com

1 Covance, The Drug Development Division of LabCorp, Princeton, NJ, USA

2 Gree Bio, LLC., Austin, TX, USA

3 Merck \& Co., Inc., Boston, MA, USA

4 Science For Solutions, LLC., West Windsor, NJ, USA

5 University of North Carolina at Chapel Hill, Chapel Hill, NC, USA

6 EPAM Systems, Inc., Boston, MA, USA
}

However, before we move on to the next author I'd like to note that these pieces don't just bid farewell to our friends, colleagues, and comp chem founders, but are also meant to tell some history of comp chem. Our field is not so old, just a few generations. Although we've lost a some of the first generation, many of these founders are still with us. We still have the golden opportunity to learn from them. They started our field on its way and much of what we do as computational chemists is based on their insight. Also, some of what we routinely do is based on the shortcuts that were essential for their work 40 or 50 years ago. Had they the same information and computational resources that we have now it's clear from their literature and from discussions with some of them that they would now do things differently. However, although a lot of substantial new advances have taken place, some aspects of our work have become rote and some of those shortcuts are still buried deep in our software and habits. Understanding history can give us a better idea of how to improve what we do.

As a timely note, there will be a symposium in Franks honor Monday August 20, 2018 at the American Chemical Society's 256th National Meeting in Boston, MA.

\section{Mirrors}

\section{Dimitris Agrafiotis}

I still remember the day when the terrible news of Frank's untimely passing hit my mailbox as if it were yesterday. I was so saddened and shaken that I decided to drop everything I was doing and write a short note on LinkedIn to let his many colleagues and friends know that he was no longer with us. In that note, I tried to capture in a few short lines a lifetime of innovation, impact, and achievement-and a man that I've got to know and appreciate more and more as the years went by: 
What a terrible way to start the week. Yesterday I was informed about the sudden and untimely passing of my former colleague and friend Frank Brown. I just wanted to share the sad news with his professional family around the world, so I will be relatively brief. Frank was one of the founders and leading figures of the field of cheminformatics, and one of the brightest, most innovative, and most genuine individuals I have ever met. He was a man of razor-sharp intellect, contagious enthusiasm, incurable optimism, and a genuine passion for helping his colleagues. His dedication to his craft, his creative yet pragmatic approach to science, and his empathy for the bench scientists, the ultimate recipients of his work products, were unrivaled, as was his commitment to the people and the companies he worked with and for. Our paths crossed many times, both professionally and personally, and were on the verge of crossing once again had fate not stood in the way.

I've always had enormous respect for Frank for his scientific and professional achievements, but my respect soared to new heights as I got to know him more as a person. The common link was our children who were at the same age and attended the same college. I still remember the day when my daughter and I ran into Frank and his brilliant son Tim at the Coop at Berkeley during the freshman orientation day. I wish I had a camera to capture the joy and pride on his face. In the months and years that followed, Frank's human qualities and his loyalty to his family became more and more evident to me. He loved his wife to whom he was married for more than 30 years, and was unbelievably proud of his children and their achievements. He glowed every time he talked about them, he would go on and on for hours, not to boast but simply because he admired them.

Most people go through life without recognizing what impact they have on the world around them. Frank's impact was outsized. I will remember him always with great affection and admiration, and I will miss him terribly. Many people will. My thoughts are with his family and loved ones.

When his son Kyle asked me to read that note at Frank's funeral, I was touched and humbled beyond words. I think many of our common friends were surprised by how emotional I was when I delivered that eulogy. After all, Frank and I were never really close friends and did not socialize much outside of work. Where did that emotion stem from? What was it that people couldn't see?

In truth, Frank to me was a mirror; in it, I saw pieces of myself. Pieces I liked, and pieces I wish others would spend more time to understand. Apart from his brilliance, his creativity, his tenacity, his dedication, his optimism, Frank was genuine. And in a world of fake "realities", of distorted online personas hiding uncomfortable truths, of polished facades that mask our inner selves, I will take genuine every day. These shared memories of Frank suggest that most of us would.

\section{Learning from the master}

\section{Alexander Tropsha}

Computational chemists are a unique community of scientists. Many of us work, or more precisely, have to operate at the interface between computational and experimental sciences. Many of us make ourselves busy inventing new algorithms that should change the practices of experimental scientists and guide their studies but for the most part we do not conduct experiments. Playing at this interface requires many technical as well as social and intercultural skills, and while research administrators and funding agencies have started pushing for interdisciplinary and convergent science in the past decade only, many of us have lived these paradigms for much longer.

Perhaps very few have mastered the skills of the boundary player as well as Frank Brown. Indeed, his research career has captured, perhaps in the most illustrious way, the major pillars of computational chemistry and molecular modeling, namely deep theoretical background, software development, and applied studies. As a graduate student and a postdoc, Frank studied with the giants of computational chemistry such as Ken Houk and Peter Kollman and then worked successively (and successfully!) alternating between Pharma and molecular modeling software industry. In retrospect, it all makes a clear sense. Starting an industrial career in Big Pharma in the 80-ies required strong theoretical background; thus Frank had little difficulty landing his first jobs at SmithKline and French and Glaxo. But then, after a few years of experiencing challenges faced by the industrial computational chemists, he thought of improvements in existing commercial software that could be seen only if working in the field, not in the software development lab. Articulating these needs led to Frank's recruitment by Oxford Molecular, one of the software vendors for Glaxo. Conversely, staying in the software company for too long could result in disconnect with the needs of real life in drug discovery companies; this is how Frank went back to pharma industry, this time working for Johnson \& Johnson. And then he went back to software company, this time Accelrys. And then back to Pharma, this time Merck, which turned out to be his last job.

Every job move was accompanied by assuming a higher level administrative position with greater responsibilities; but most importantly, with every move Frank grew as an 
industrial scientist and visionary in the field, and he always generously shared his wisdom and knowledge with his colleagues. These days in academia we attempt to teach our students how to be agile and adaptive to rapidly changing work and societal environment: Frank could serve as a role model for the current generation of students as a person who lived these traits all his life. I am sure it is for this unique ability to stay attuned to all current and emerging trends in both theory and practice of computational drug discovery that he was able to coin, before others, the term chemoinformatics, an accomplishment which he is mostly known for outside of our field.

I met Frank soon after I moved to Chapel Hill as a postdoc at UNC in September of 1989 and have stayed in contact with him practically until his last days. In fact, I was preparing for a teleconference with Frank to discuss his possible recruitment to UNC when I got a phone call from a common friend on a Sunday afternoon, January 29 of last year, with the sad news, which meant the call the next morning would not happen due to the most tragic reason one could imagine.

When I met Frank in 1989, he was a group leader at Glaxo; and soon after he started his real job, he was also "recruited" by my predecessor at UNC, Phil Bowen, to teach a couple of guest lectures for the Molecular Modeling class in the School of Pharmacy. I've got to interact with Frank even more the next academic year of 1990/1991 when Phil left for the University of Georgia and Frank, in his graceful way (which as I and others have learned over the last nearly 30 years was his nature) volunteered not only continue to teach his lectures but take over the entire year-long course. This was indeed an act of a selfless contribution, so characteristic of Frank-the-human-being, as it allowed my Division and the School to continue to offer a course that was widely popular across many departments at UNC while searching for a permanent faculty to take over the Molecular Modeling Laboratory and the teaching duty. I was ultimately offered this job, and I am forever grateful to Frank for supporting my recruitment and for sharing his lecture notes, his expertise, and staying as a guest lecturer until he left Chapel Hill. I was also fortunate to "inherit" his teaching assistant Chris Waller whom Frank trained so well and who became my life-long friend.

Frank was just a little older than me but I always regarded him as a senior colleague and friend as he always knew so much more and always took time to explain and share in response to my questions and requests, whether it was about science or life. I can recall many encounters and conversations over so many years (and for a few years we even lived in the same neighborhood) that we have known each other but I shall name a few that in my memory reflect on Frank's impact on me and others. I already mentioned how Frank helped my school with teaching a class and how he helped me launch my academic career. A couple of years after I met
Frank, he helped another young scientist to stay at UNC and in the US by funding his position in my lab when no other sources of funding were available; this led to a new line of research in the lab and our first joint publication with Frank. And this was just one of many examples when Frank took time to help people.

Thinking about people he has worked with and helping them was Frank's distinct trait. We had many conversations with Frank about his career in industry and especially, at Merck where he held a senior leadership position. Once he came to a symposium at UNC and stayed for a few days; and I was totally puzzled by him giving full attention to other talks and never using his cell phone during the entire symposium, something I have never observed with any high level industrial scientist and/or administrator. I questioned him about this, and his answer was that he has spent a lot of time early on building a team of superior scientists whom he trusted and who needed little management. But what also struck me was how his face lit up when he talked about people in his team and how he was proud that he enabled them to realize themselves. And to recall how broad his thinking about trends both in science and the society was, one day he said that he suddenly realized that in more than 20 years of interviewing thousands of job candidates for the companies he worked for only once was the applicant the African American. And then I arranged for him to talk to our Associate Dean for Diversity whom Frank connected with her peer at Merck.

As I said, there are many memories of conversations and interactions with Frank that I cherish and that I will be coming back to as we continue our lives without Frank. He loved life and people in general, especially his family that one way or another he would always reflect on in our conversations, and he loved science and scientists. Those of us who knew him will always remember his quiet smile and his stories full of context and humor. I hope that this brief note will let those who only knew Frank by name associate this name not only with the term chemoinformatics but also with a real person whose life has made impact on so many of us.

\section{A visionary leader and mentor}

\section{Scott Arne Johnson, Merck \& Co., Inc.}

Did I ever tell you the history of the lightbulb industry? When lightbulbs first came out, they all required different socket sizes. If you went out to buy a lamp, it had a particular socket and you could only buy certain lightbulbs. Once everybody stopped trying to make a better socket, a marketplace of lightbulb makers and lamp makers flourished. Every industry starts highly stylized and compartmentalized, and ours is no differ- 
ent. I've spent my life pursuing that same philosophy, and I see the light at the end of the tunnel. We are going to evolve this industry to a single platform, and the opportunity is mind-blowing.

I furiously wrote this down towards the end of a software strategy meeting with Frank, where I had mistakenly believed that the conversation had long derailed. That meeting, like most meetings with Frank, had four parts where he would: (1) beam with pride while giving updates about his family; (2) ask about your family; (3) carefully listening while you explained your problem; and finally (4) tell you why you were actually there and pass along his greatest gift, his vision.

One would find it impossible to avoid becoming swept up in his enthusiasm and the magnitude of his plans to transform the way in which technology enables science on a worldwide scale. It took a while to sink in, but I realized later that our meeting hadn't derailed at all. I was too caught up in the immediate problems at the time to see the forest through the trees, that my woes would never actually be solved without first "thinking bigger." The story of the lightbulb industry exemplified the core of Frank's vision for the scientific field: stop reinventing methods and technology that yield marginal return and focus on enhancing collaboration.

His message also carried an undertone that perfectly highlights his personal perspectives on success: don't spend your time reinventing a marginally better wheel; and invest in "raising the tide" to elevate everybody, and you will ultimately elevate yourself. There is a lot of humility and generosity in those perspectives, which in addition to perseverance and stubbornness, were some of Frank's strongest qualities. His path to success was based on first acknowledging the successes of others, building on them, and finally sharing the results with the world to continue the cycle. Frank dreamed of one day defining the universal socket in the scientific software and methods development world. His goal was to build a marketplace driven by quality of science rather than differences in implementations or marginal improvements. He used to say that our field will only begin to experience transformative change once we move from "me to we." His goal was to spend the next phase of his career being the flame to spark that mindset change, and now it falls upon all of us to carry the torch.

Frank was the consummate mentor. It didn't matter if you were his boss, half-a-dozen levels down the organizational chart, or in an entirely unrelated field of work. He always had something to teach. We first met when I spent a summer as a graduate intern at Accelrys. I found the most valuable lessons learned that summer had nothing to do with science or even industry experience, but rather from the hours spent dreaming up big industry-changing ideas, evaluating them strategically, and then forming realistic tactics that might take the first baby steps in those directions. Those moments reflected the true patience, generosity and humbleness of Frank in a nutshell: a successful scientist and executive spending hours passing on a lifetime of experience to a naïve graduate student that he had only just met. Frank's style of mentorship and leadership were as frustrating as they were empowering for those under him. We were expected to take risks and occasionally fail as long as we satisfied the following two criteria: (1) taking ownership and accountability for your actions, and (2) "passing the red face test" when confronted about your decisions. For mentoring upwards, Frank had a number of different tactics. My favorite, and probably the most memorable, was when he needed to convince his boss' leadership team to resource a strategic initiative that challenged the historical organizational culture. I asked him what he planned to say, and his response was "I plan on walking in that room and dropping the verbal equivalent of a grenade on the status quo, then once the dust settles, helping them understand why this strategy makes us even better in the end." I followed up by asking whether or not he thought that tactic would work, to which he responded, "I'll let you know if I'm still working here after the meeting." That fearlessness, strength in his convictions, and wry humor in the face of adversity is the other side of Frank that many of us will always remember.

\section{Thinking big}

\section{Katharine Holloway}

I first met Frank Brown in 1987 when I was still a relatively new hire in the computational chemistry group at Merck and he was interviewing for a position there. He was then a post-doc with Peter Kollman at UCSF carrying out free energy perturbation calculations on triose phosphate isomerase (TIM). Yes, FEP was a hot new approach back in the late 1980s! Frank didn't become my colleague at that time, though. Instead, he accepted a job at SmithKline Beckman (SKB) down the road. However, he only spent a couple of years at SKB before moving on to Glaxo where he stayed until 1996. Frank always liked to say that he worked for Glaxo and he worked for SmithKline but he never worked for GlaxoSmithKline (GSK) which came into existence when the two companies merged in 2000 after he had already moved on to Oxford Molecular, where he spent a year or two doing a whole lot of travelling. With two young sons by then, his wife Hilary strongly encouraged him to find something a little more settled. So, he moved again to Johnson and Johnson where he spent the longest stint of his career from 1997 to 2007. Then he was off again to Accelrys before finally joining Merck in 2012. His career had surprisingly come full circle. 
Computational chemistry is a rather small world and this was especially true in the early days. As such, our paths crossed often professionally, particularly at ACS meetings where Frank, my husband Chuck Reynolds, and I were all very involved with the Computers in Chemistry division, each taking turns as COMP chair over the years. By 2000, Frank had also recruited Chuck to work for him at J\&J, running the modeling group at the Spring House, PA site. As it turned out, I would also end up working for Frank when he was recruited to Merck to completely reimagine our cheminformatics tools and their use in drug discovery. After all, Frank had been in the vanguard of cheminformatics dating back to his time at Glaxo, carrying through to $\mathrm{J} \& \mathrm{~J}$, and especially at Accelrys. He liked to claim that he actually coined the term cheminformatics. Although ... if you read his earliest publication carefully, he used a slight variation, "chemoinformatics", which was ultimately shortened to "cheminformatics". But let's not quibble over semantics. Frank clearly had a very early vision of how the combination of information and modeling could help drive the invention process.

He ultimately distilled this at Merck into a Design-MakeTest cycle in which Design First! was an imperative. This would not have been enough, though, to convince medicinal chemists if he had not also ensured that the tools were made simple and easy to use and brought directly to the scientist instead of the scientist to the tools. Using well-validated, internally developed, QSAR models for physical and pharmacokinetic properties, he orchestrated the implementation of property prediction in common chemistry tools such as ChemDraw, Excel, and PowerPoint. There was no longer any excuse for not predicting properties in advance of synthesis and using that information, at least in a categorical enrichment sense, to evaluate designs and track project direction. This heightened sense of strategically focusing both early and late stage discovery chemistry projects was eventually embraced at Merck. Much of this monumental shift could be attributed to Frank's highly visible efforts to sell the concept at a time when the discovery process was ripe for a change, but a lot of this was as a result of his expertise in behindthe-scenes maneuvering to get things accomplished. Frank was nothing if not a master strategist, constantly thinking 2 or 3 moves ahead of everyone else, figuring out how to obtain necessary assets, either directly through persuasion, indirectly through targeted collaborations, or occasionally through bold "land grabs".

To Frank, navigating the corporate world was like a giant game of chess, or perhaps his favorite sport, golf. When he was not in the office, he was often to be found in what he called "the green room", i.e. the golf course. At work, he was always trying to up his game and expected us to do the same. There were the "first $40 \mathrm{~h}$ " when you did your actual job and the "second $40 \mathrm{~h}$ " where you did all the things that help get you your next job, like publishing, presenting your work, and participating in strategic initiatives. He tried to get all of us to think strategically, suggesting that we all read and take to heart the lessons in the book "Good to Great". In both leadership and departmental meetings, we were often charting and reviewing strategy. Of course, his response to our strategy suggestions was more often than not something like, "That isn't a strategy, that's a tactic"; "Think bigger!"; and "Better to ask forgiveness than permission". One really important lesson was to bring relevant folks outside the department into the strategy process so they "owned it" and were ultimately accountable too. As Frank used to say, "Everyone's baby is beautiful". As a result, structure, modeling, and informatics began to feature in many high-level Merck research presentations as they had rarely done before.

He embraced the slogan that "a rising tide lifts all boats" which he interpreted to mean that developing all the members of his organization could only be beneficial. Hence, he was constantly striving to improve and grow his current group of scientists and make them think and work as a team. As he put it, "Getting from Me to We". At Merck, his department of mostly $\mathrm{PhDs}$ had long operated essentially as independent contractors. One previous group member even likened it to "a collection of prima donnas with no corps de ballet". Operating as a team was a novel concept to some, and at first a hard sell, but Frank was nothing if not a good salesman. During his tenure at Merck, the department, which included modeling, informatics, and protein structure scientists, significantly increased in cohesiveness, as well as dramatically in size and scope. As part of this process, he focused on improving the diversity of the organization as well as its scientific capabilities. As a result, the number of women and under-represented minorities he recruited, mentored, and promoted, contributed significantly to bettering the overall numbers for the chemistry department as a whole, a notoriously male dominated discipline in the pharma industry.

All of this is not to idealize Frank. He could also be a royal pain in the ass when he wanted something and he wanted it yesterday. Or if he had a strategic plan and your chess piece didn't fit what he had in mind. And he brooked no whining. He always said "Don't bring me problems unless you bring me solutions". That said, if you could present him with a different plan or idea, he would listen carefully and if he felt that it had merit he could be persuaded to change his view.

I cannot think of words to express how sad I was (and still am) at Frank's passing. It's hard to imagine all that energy, enthusiasm, and zest for life being stilled. He was certainly a tough but terrific boss, mentor, and friend to me. He was also a visionary in his field, a phenomenally strategic thinker, and someone who could almost always inspire/cajole/coerce others to get on his bandwagon. In 
addition, he was a really interesting person to talk to, with a rich fund of wonderful stories, a number of eclectic interests (e.g. wine collecting), and always an engaging boyish optimism. Frank handled even difficult times with grace and humor. He will be sorely missed by all who knew him.

\section{Remembering Frank}

\section{Chris Waller}

It's difficult for me to express how knowing Frank changed my life. You see, I met Frank during my second year in graduate school at UNC-CH. Frank held an adjunct professor position in the School of Pharmacy and had stepped in to run the Laboratory for Molecular Modeling while we recruited a new faculty member (Alex Tropsha). I was Frank's Teaching Assistant.

He was only a few years older than me but he and already established himself as the father of Cheminformatics at Glaxo. I knew almost immediately after meeting him and seeing how much joy he got out of his work and his life that I wanted to follow a similar career path. One afternoon after a lab session, I explained this to Frank and told him that I'd like to join him at Glaxo. In typical Frank style, he explained that he'd never hire me. He did give me great advice though and encouraged me to call Garland Marshall. And that made all the difference.

Over the course of 25 years or so, Frank and I had had many opportunities to work together in my various roles in pharma and his on the software side. We shared a love for good food, good wine, good beer, and generally creating change in our industry. In 2012, I left Pfizer for a life of independent consultancy. Sitting on my office (boat) one afternoon I got a call from Frank. In typical Frank style again he explained that he needed to hire me to help him establish a Cheminformatics team at Merck. 25 years is a long time to be interviewing for a job.

In any event, we worked together for 4 years or so-and changed the world.

My life changed dramatically as a result of Frank entering it. And, it changed dramatically with his passing. It's been over a year, and I still find it hard to imagine a day without Frank-and some silly saying like "we're going to get it wrong before we get it right". I wish I had written all of them down. Maybe we can crowdsource a Frank Brown's Almanac? Maybe call it Frank-isms.

Frank was an excellent mentor and dear friend to me for a large portion of my life. I do miss him, daily, but am grateful and am blessed to have known and learn from him. Thanks for the memories.

\section{Thanks for the sticky fingers}

\section{Chuck Reynolds}

The computational chemistry community is small so of course I knew Frank originally from a few chance encounters at meetings and the like. But I really got to know him during the middle 90s when we were both candidates for chair of the ACS Computers in Chemistry Division. We ended up being back-to-back chairs and worked together on a number of projects to develop the division, raise our visibility in ACS, and most controversially establish a relationship with Elsevier to promote publication of computational chemistry work. At the time the ACS was not very receptive to creating a journal for the newly emerging field. That didn't stop them from being just a little upset with us for throwing in with the "Great Satan of the Netherlands." I'm a little loath to mention this now, since I have been on the ACS Publications Committee for quite a while and I don't think anyone there knows or remembers that subversive episode, or my part in it. Frank enjoyed it and he had the honor of actually signing the contract.

We discovered in those days that we had a lot in common and, at least I would like to think, became good friends. So it was that in 1999 I got an email from Frank asking me for candidates to manage the CADD groups at J\&J. I was working at Rohm and Haas (now Dow Dupont) and could literally look out my window at the J\&J Spring House site. Moreover, the Life Sciences part of R\&H was looking iffy, with rumors of divestiture in the air, so I emailed back "what about me?" It seemed like my phone rang before I hit enter. Leaving out the details and a bit of J\&J palace intrigue, it wasn't too long before I was based at the J\&J Spring House site and reporting to Frank (at least initially) in Raritan. We had a lot of complementary interests and, I think, complementary strengths. He was a good mentor, helping me to assimilate into the giant and unfathomable behemoth that was J\&J. I started recruiting modelers and we worked with scientists and IT groups across sites in the US and Europe to bring in or develop a range of new software, hardware, and assorted tools for both modeling and informatics. For example, we were early adopters of Pipeline Pilot and some of the OpenEye tools. Mark McGann, currently of OpenEye, was a postdoc in Spring House developing his Fast (well ask Mark about the prototype name) docking program with Frank and Hal Almond from my group.

Frank used to tell me that his stint at Oxford Molecular was his hard knocks MBA. I had a gentler experience with Frank, learning the intricacies of J\&J accounting for example. The basics came from all the management courses $\mathrm{J} \& \mathrm{~J}$ required, but the secret sauce was Frank's. He taught me 
that there were always clinical trials that didn't fill their enrollments and the department heads would be desperately looking for help spending their money so as to avoid a cut in the following year's budget. I can't touch Frank's haul, but even on the modeling side I was able to virtually double our budget by graciously spending other people's money at the end of the year. This was all Frank's idea of course. I was clueless. But I learned. The Christmas holidays became a lot less relaxing as I was always checking in, from wherever, with our accounting representative and multiple vendors. The key was getting everything accrued to the current year by satisfying all the $J \& J$ accounting rules. One of those rules was to actually receive the item before December 31. I won't say we once (OK maybe more than once) just received a box of parts from a computer vendor, but I will say some assembly was definitely required. I inherited the software and hardware budgets for the US CADD sites and with the growth of groups in Spring House, Raritan, and La Jolla we were buying a lot more software in particular. Frank simply loved negotiating contracts. And I do mean loved it. In fact, I remember one time when he was telling me how much he loved buying new cars. I mean who likes that? I hate negotiating contracts, and I think his biggest disappointment in me was that I just wasn't as enthusiastic or good at it. I was like the easy parent the kids, in this case vendors, tried to use to get around the tough parent. I guess this was my practical MBA and it served me well when I went on first to a small biotech and then to my own company.

Frank and I were both traveling quite a bit to the west coast site and the Janssen site in Belgium. I remember my first trip to Belgium. It was the usual parade of back-to-back meetings. But we happened to be there during the time $\mathrm{J} \& \mathrm{~J}$ was looking at bringing Tibotec into the fold, and Frank and I were asked to meet with them. They were housed at what I believe was one of the (I don't know how many) houses owned by the legendary founder of Janssen, "Dr. Paul." Frank and I happened to be in the right place at the right time and were introduced to Dr. Paul during our visit. I'm pretty sure that is the only time I have ever shaken the hand of a billionaire. We stayed in the center of Antwerp, a beautiful city. I remember us going for dinner one night. We settled on a nice looking outdoor café and then set about ordering. The server obviously saw us coming (i.e. stupid Americans) and maneuvered us into ordering some kind of special dinner. It turned out not only to be the most expensive item on the menu, but a huge and unfamiliar pile of mostly seafood items. We were sort of figuring out that we had been played, but at least we had plenty of food even if we weren't exactly sure what a lot of it was. I remember Frank biting into what looked like a huge scallop and freezing mid bite. "It is raw" he mouthed with the thing still in his mouth, and then he took a few chews and swallowed it whole. It took a while for the color to return to his face and I knew he was a better man than me. I think I would have spit it out. I learned to stick to the moules-frites, chocolate, and Abbey triples.

We kept up with each other after J\&J, even discussing some opportunities to work together that didn't pan out. When he was looking to move to Merck we talked at length about the opportunity and I provided a recommendation for him. It was a little strange since of course my wife Kate Holloway was there and would be working for him. I know there was some adjusting for both Frank and Merck, but Kate has spelled out his impact there in her remembrance. I got to hear about how things were going from occasional lunches with Frank and more frequent reports from Kate. I also got to know Frank's wife Hilary better since we were in the same geographic location, really for the first time. When he was leaving Merck, we talked quite a bit about his starting a consulting business, which was to be his next gig. I had done it a few years previously and knew some of the ins and outs. We talked about potentially collaborating again through our respective companies. This was something I was looking forward to doing, and the opportunities have certainly been there, if he were only still with us. Most of all we enjoyed talking about the plans Kate and I had to move to Austin and the plans he and Hilary had to move to North Carolina. We both had ample space in our new houses for visitors and we fully expected to trade visits with them. Indeed, we were in Austin literally taking possession of our new house when the devastating news arrived in the form of a phone call. I knew from the expression on Kate's face that something terrible had happened.

One of the last times we saw Frank was at his Merck going away lunch where he cemented our plans to exchange visits with a bottle of Sticky Fingers North Carolina style barbecue sauce. I still owe him a bottle of "real" barbecue sauce from Austin's Salt Lick. 